\title{
Даниленко Н.Е. \\ К вопросу об основаниях и условиях рассмотрения уголовного дела в особом порядке судебного разбирательства при согласии обвиняемого с предъявленным ему обвинением
}

Ростовский филиал ФГБОУ ВО «Российский государственный университет правосудия»

doi: 10.18411/lj-04-2021-225

(Россия, Ростов-на-Дону)

Научный руководитель

Блинников В.A.

\section{Аннотация}

В статье рассматривается один из дискуссионных вопросов особого порядка судебного разбирательства, связанный с определением оснований и условий его применения. Анализируются различные точки зрения ученыХ-процессуалистов по определению оснований и условий применения данной формы судебного разбирательства; исследуется содержание норм уголовно-процессуального закона по рассматриваемому вопросу. Делается вывод о том, что необходимо различать основания и условия применения особого порядка судебного разбирательства, предлагается авторское понимание содержания данных категорий. Кроме того, вносятся предложения по внесению изменений в действующий УПК РФ.

Ключевые слова: уголовное судопроизводство, особый порядок судебного разбирательства, согласие обвиняемого, заявление ходатайства, основания, условия.

\section{Abstract}

The article deals with one of the controversial issues of a special order of court proceedings related to the determination of the grounds and conditions for its application. Various points of view of legal scholars on the determination of the grounds and conditions for the application of this form of legal proceedings are analyzed; investigates the content of the norms of the criminal procedure law on the issue under consideration. It is concluded that it is necessary to distinguish between the grounds and conditions for the application of a special order of court proceedings, the author's understanding of the content of these categories is proposed. In addition, proposals are being made to amend the current Criminal Procedure Code of the Russian Federation.

Keywords: criminal proceedings, special order of trial, consent of the accused, application of a petition, grounds, conditions

По официальным данным Судебного департамента при Верховном Суде РФ, в последние годы более $60 \%$ уголовных дел рассматриваются в особом порядке судебного разбирательства [11], который, как показывают результаты судебной практики, давно потерял качество «особенного», став типичной формой уголовного судопроизводства [7, с. 5].

Необходимо отметить, что как до принятия действующего Уголовнопроцессуального кодекса Российской Федерации (далее по тексту - УПК РФ), так и после его вступления в законную силу ряд ученых-процессуалистов в своих работах поднимали проблемные вопросы особого порядка судебного разбирательства. Так, одним из дискуссионных по сегодняшний день вопросов, носящий как практический, так и теоретический характер, является проблема определения оснований и условий применения особого порядка судебного разбирательства при рассмотрении уголовных дел.

Если обратиться к названию ст. 314 УПК РФ, то можно увидеть, что законодатель говорит об основаниях применения особого порядка судебного 
разбирательства [1]. Однако, проанализировав содержание данной статьи, мы видим, что в ней говорится не только об основаниях, но и об условиях. Получается, что законодатель, используя оба понятия (основания и условия), как в названии, так и в тексте ст. 314 УПК РФ, не проводит разграничения данных категорий, и, соответственно, оснований и условия применения гл. 40 УК РФ.

К сожалению, в научных трудах, предметом которых выступил особый порядок судебного разбирательства, также отсутствует единый подход к решению вопроса о разграничении оснований и условий применения данной формы судебного разбирательства.

Так, вслед за законодателем одни ученые-процессуалисты также не различают основания и условия применения особого порядка судебного разбирательства [14, с. 266], рассматривая их во взаимосвязи как сложную структуру [9, с. 60].

Другие ученые говорят о необходимости разграничения оснований и условий применения особого порядка судебного разбирательства. При этом, по мнению А.Ф. Ефремова «в качестве правовых оснований применения особого порядка судебного разбирательства выступают правовые предпосылки, возникающие до начала рассмотрения уголовного дела» $[10$, с. 56], а по мнению А.И. Ивенского «условиями применения особого порядка судебного разбирательства выступают обстоятельства, установленные в результате проверочных действий, проведенных судом, при наличии полного набора которых суд получает право вынести приговор в сокращенные сроки» $[5$, c .6].

Считаем необходимым различать основания и условия. Без наличия фундамента, который является базисом, отправной точкой, достичь цели невозможно. Но для получения результата, в нашем случае - рассмотрения дела в особом порядке судебного разбирательства, необходимо выполнение условий, зависящих от возможности применения данного порядка. Таким образом, для рассмотрения дела в особом порядке судебного разбирательства необходимо соблюдение как оснований, так и условий. При этом в качестве правовых оснований для применения особого порядка судебного разбирательства по уголовному делу необходимо учитывать правовые предпосылки, а условия должны включать обстоятельства строго фактического плана.

Придерживаясь точки зрения ученых, разграничивающих основания и условия применения особого порядка судебного разбирательства, следует констатировать, что на сегодняшний день так и не сложилось единого понимания по вопросу о том, какие обстоятельства следует отнести к основаниям, а какие - к условиям применения особого порядка судебного разбирательства. В связи с отсутствием единого подхода по данному вопросу рассмотрим различные позиции относительно определения оснований и условий применения особого порядка судебного разбирательства по уголовному делу и предложим свое видение данных категорий.

В соответствии с положениями ст. 314 УПК РФ - обвиняемый вправе согласиться с предъявленным ему обвинением и ходатайствовать о постановлении приговора без проведения судебного разбирательства в общем порядке по уголовным делам о преступлениях небольшой или средней тяжести. В этом случае суд, как следует из закона, вправе вынести приговор без проведения судебного разбирательства в общем порядке, если он убежден, что:

1) обвиняемый осознает характер и последствия заявленного им ходатайства;

2) ходатайство было заявлено добровольно и после проведения консультаций с защитником;

3) государственный или частный обвинитель и (или) потерпевший не возражают против заявленного обвиняемым ходатайства.

Однако у ученых-процессуалистов есть своя точка зрения по данному вопросу. Так, С.А. Есенкулова выделяет только одно основание рассмотрения уголовного дела в особом порядке судебного разбирательства «это ходатайство обвиняемого об особом 
порядке судебного разбирательства. Условия - это обстоятельства, без которых невозможно существование определенного явления или осуществление каких-либо действий» [4, с. 14].

Согласно точке зрения А.В. Кищенкова, «основанием для применения особого порядка принятия судебного решения являются положения, сформулированные законодателем в ч. 1 ст. 314 УПК РФ, а именно: 1) наличие согласия обвиняемого с предъявленным ему обвинением; 2) наличие ходатайства обвиняемого о вынесении приговора без проведения судебного разбирательства; 3) наличие согласия потерпевшего на вынесение приговора без судебного разбирательства; 4) отсутствие у обвиняемого свойств особого субъекта; 5) наличие согласия государственного или частного обвинителя» [6, с. 19].

По мнению Т.Я. Хабриевой «необходимо наличие лишь оснований в качестве достаточности удовлетворения ходатайства обвиняемого о применении особого порядка судебного разбирательства: 1) согласие обвиняемого с предъявленным ему обвинением; 2) обвиняемым заявлено ходатайство о постановлении приговора без проведения судебного разбирательства в общем порядке» [13, с. 256].

Обобщая рассмотренные мнения ученых-процессуалистов, мы приходим к выводу, что только ходатайство обвиняемого следует отнести к основаниям применения особого порядка судебного разбирательства. Полагаем, что под данным основанием следует понимать правовые предпосылки, которые должны возникнуть перед началом судебного разбирательства уголовного дела, и только их наличие позволяет суду определить возможность рассмотрения уголовного дела в упрощенном порядке. Иные обстоятельства связаны с условиями, их наличие без обращения подсудимого к рассмотрению дела в особом порядке не меняет форму судебного разбирательства.

Далее, из положений гл. 40 УПК РФ, следует, что к условиям применения особого порядка судебного разбирательства относятся следующие обстоятельства:

- заявление обвиняемым ходатайства в момент ознакомления с материалами уголовного дела (абз. 1 ч. 2 ст. 315 УПК РФ) или на предварительном слушании (абз. 2 ч. 2 ст. 315 УПК РФ);

- согласие обвиняемого с предъявленным ему обвинением (ч. 1 ст. 314 УПК РФ);

- предъявление обвинения в совершении преступлений небольшой или средней тяжести (ч. 1 ст. 314 УПК РФ);

- отсутствие возражений государственного (или частного) обвинителя и потерпевшего против ходатайства, заявленного обвиняемым;

- заявление ходатайства добровольно и после проведения консультаций с защитником (п. 2 ч. 2 ст. 314; ч. 1 ст. 315 УПК), а также осознание обвиняемым характера и последствий заявленного им ходатайства осведомленности о характере и последствиях своего ходатайства (п. 1 ч. 2 ст. 314 УПК РФ);

- обоснованность обвинения подтверждается собранными по уголовному делу доказательствами (ч. 7 ст. 316 УПК РФ).

Однако данный перечень нельзя признать исчерпывающим. Так, согласно п. 2 Постановления Пленума Верховного Суда РФ «О применении судами особого порядка судебного разбирательства уголовных дел» устанавливается дополнительное условие, которое не названо в гл. 40 УПК РФ «отсутствие оснований для прекращения уголовного дела» $[12]$.

Помимо указанных выше условий особого порядка, в литературе дополнительно выделяются признание вины обвиняемым [2, с. 83], необходимость возмещения вреда, причиненного потерпевшему [8, с. 260], и отсутствие возражений со стороны обвиняемого по предъявленному гражданскому иску [3, с. 75]. Эти условия неоднозначны в научной литературе. 
Разнообразие мнений и подходов к определению оснований и условий применения особого порядка судебного разбирательства свидетельствует о необходимости законодательного уточнения перечня оснований и условий для предотвращения необоснованного расширения списка и необоснованного ограничения прав обвиняемого по уголовному делу.

Таким образом, под основанием применения особого порядка судебного разбирательства мы предлагаем понимать ходатайство обвиняемого о вынесении приговора без проведения судебного разбирательства в общем порядке. Все остальные требования, перечисленные законодателем в гл. 40 УПК РФ, выступают условиями применения данного порядка, а именно: согласие государственного или частного обвинителя и потерпевшего; совершение обвиняемым преступления небольшой или средней тяжести; осведомленность обвиняемого о характере и последствиях поданного им ходатайства; ходатайство было заявлено обвиняемым добровольно и после консультации с защитником; обвинение, с которым согласился подсудимый, обосновано и подтверждено доказательствами, собранными по уголовному делу.

Считаем, что основания и условия применения особого порядка судебного разбирательства должны быть четко обозначены и перечислены законодателем в одной из норм гл. 40 УПК РФ. В связи с этим предлагаем ст. 314 УПК РФ изложить в следующей редакции:

«Статья 314. Основания и условия применения особого порядка судебного разбирательства.

1. Основанием применения особого порядка судебного разбирательства является ходатайство обвиняемого о вынесении приговора без проведения судебного разбирательства в общем порядке. являются:

2. Условиями применения особого порядка судебного разбирательства

1) признание обвиняемым вины в совершении преступления и согласие с предъявленным ему обвинением

2) обвиняемому инкриминируется преступление, наказание за которое, предусмотренное Уголовным кодексом Российской Федерации, не превышает пяти лет лишения свободы;

3) обвинение, с которым согласен обвиняемый, обосновано и подкреплено доказательствами, собранными по уголовному делу;

4) обвиняемый осведомлен о характере и последствиях поданного им ходатайства;

5) ходатайство заявлено добровольно и после проведения консультации с защитником;

6) государственный или частный обвинитель и потерпевший соглашаются с ходатайством обвиняемого о вынесении приговора в особом порядке судебного разбирательства.

3. Если суд установит, что основания и условия применения особого порядка судебного разбирательства, предусмотренного частями первой и второй настоящей статьи, не соблюдены, то он принимает решение о назначении судебного разбирательства в общем порядке».

\section{$* * *$}

1. Уголовно-процессуальный кодекс Российской Федерации от 18.12.2001 № 174-Ф3 (ред. от 24.04.2020) // Собрание законодательства РФ. - 24.12.2001. - № 52 (ч. I). - Ст. 4921.

2. Арсенова Н.В. Основания и условия применения особого порядка принятия судебного решения при согласии обвиняемого с предъявленным ему обвинением // Актуальные проблемы борьбы с преступлениями и иными правонарушениями: материалы IX Междунар. науч.- практ. конф. Барнаул, 2011.

3. Великий Д.П. Особый порядок судебного разбирательства: теория и практика // Журнал российского права. - 2005. - № 6. 
4. Есенкулова С.А. Упрощенный порядок судебного разбирательства в уголовном судопроизводстве (по материалам Кыргызской Республики и Российской Федерации): Автореф. дис. ... канд. юрид. наук. - М., 2013.

5. Ивенский А.И. Приговор - акт правосудия, осуществляемого в общем и особом порядках судебного разбирательства: Автореф. дис. ... канд. юрид. наук. - Саратов, 2006.

6. Кищенков А.В. Упрощенные производства: проблемы теории, законодательного регулирования и правоприменения: Автореф. дис. ... канд. юрид. наук. - Владивосток, 2010.

7. Колоколов Н.А. В поисках convenient criminal law // Уголовное судопроизводство. - 2014. - № 1.

8. Лагуткина Н.Б. Особый порядок принятия судебного решения при согласии обвиняемого с предъявленным обвинением // Наука и современность. - 2013. - № 21.

9. Мурашкин И.Ю. Заявление ходатайства о рассмотрении уголовного дела в особом порядке // Вестник Омского юридического института. - 2011. - № 4(17).

10. Особый порядок судебного разбирательства: проблемы теории и практики: монография / науч. ред. А.Ф. Ефремов. - Саратов, 2008.

11. Официальный сайт Судебного департамента при Верховном Суде Российской Федерации. Эл. peсурс. Режим доступа: http://www.cdep.ru (дата обращения: 23.02.2021 г.)

12. Постановление Пленума Верховного Суда РФ от 05.12.2006 № 60 (в ред. от 22.12.215) «О применении судами особого порядка судебного разбирательства уголовных дел» // Бюллетень Верховного Суда РФ. - 2007. - № 2.

13. Правосудие в современном мире: монография / Под ред. В.М. Лебедева, Т.Я. Хабриевой. - М.: Норма, Инфра-М, 2012.

14. Щербина Е.В. Основания для рассмотрения уголовного дела в особом порядке // Известия Оренбургского государственного аграрного университета. - 2013. - № 4(42).

\section{Демченко А.А., Мамин А.С. \\ Методика проведения отдельных мероприятий, связанных с несанкционированным доступом к системам дистанционного банковского обслуживания}

Белгородский государственный национальный исследовательский университет (Россия, Белгород)

doi: 10.18411/lj-04-2021-226

\section{Аннотация}

Данная статья направлена на рассмотрение и анализ несанкционированного доступа к системам дистанционного банковского обслуживания. Авторы уделяют внимание правовым проблемам в данной сфере, а также предлагают решение данной проблемы.

Ключевые слова: дистанционное банковское обслуживание, вредоносная программа, денежные средства.

\section{Abstract}

This article is aimed at reviewing and analyzing unauthorized access to remote banking systems. The authors pay attention to the legal problems in this area, and also offer a solution to this problem.

Keywords: remote banking, malware, money.

Анализ практики органов внутренних дел в области несанкционированного доступа к системам дистанционного банковского обслуживания позволяет наглядно рассмотреть схему такого алгоритма. В случае попадания на пользовательский персональный компьютер, вредоносное программное обеспечение проводит анализ составляющих носителя жесткого магнитного диска, ищет определенные виды файлов по сигнатурам, которые входят в состав программного обеспечения систем дистанционного банковского обслуживания. Однако, если подобных файлов не обнаружится, то вредоносная программа ищет пути распространения через локальные сети и уже там продолжает действовать. При обнаружении результата в зависимости от найденного программного продукта, представленного разработчиками систем дистанционного банковского обслуживания, вносит дополнительные модули 